\title{
EDUCATION AND DISPOSITIONAL FACTORS AS DETERMINANTS OF CORRUPT BEHAVIOUR AMONG LOCAL GOVERNMENT EMPLOYEES IN ODEDA LGA, OGUN STATE, NIGERIA.
}

\author{
Ishola, Ajibola A. ${ }^{1}$ \\ Mobile phone: +2348036280702 , \\ email: ajibola_ishola@yahoo.co.uk \\ Kenku, Akeem.A Ph.D. ${ }^{2}$ \\ Mobile phone: +2348165275459 \\ Email: akeemkenku@yahoo.com \\ $\&$ \\ Oyewo, Rasaq. $\mathrm{O}^{3}$ \\ Mobile phone: +2348063406029 \\ email: oyeoyekanmi97@gmail.com
}

\author{
${ }^{1}$ Department of Psychology, University of Ibadan, Nigeria. \\ ${ }^{2}$ Department of Psychology, Faculty of the Social Sciences, \\ Nasarawa State University, Keffi. Nigeria. \\ ${ }^{3}$ Technical Section, Oyo State College Of Agriculture and Technology, Igbo-Ora. \\ Oyo state.
}

\begin{abstract}
The study inquired the role ofeducation and dispositional variables as determinants of corrupt behavior among local government employees in Ogun State. The study was cross-sectional survey research of the expost facto type. Three hundred and fifty (350) middle to junior level cadre local government employees were purposive sampled in the study. The participants responded to a self-report questionnaire containing standardized items measuring Narcissism $(\alpha=0.68)$, materialism $(\alpha=0.74)$, involvement in corrupt practices $(\alpha=0.77)$ scales and information on participants socio-demographic characteristics. Data was analyzed withdescriptive statistics, Pearson correlation and multiple regression analysis at $p \leq .05$ level of significance.

Results revealed that demographic and personality variables significantly predicted corruption practices among employees. The study also demonstrated thateducational attainment, materialism and narcissism correlated with corrupt practices among employees in the local governments. Based on these findings, it is recommended that government should put policy measures in place to cater for the basic needs of the employees in the local government service. There should also be more emphasis on ethics in the civil service of the state.
\end{abstract}

Key words: Educational qualification, Materialism, narcissism, corrupt behaviour, Local government employees

\section{INTRODUCTION}

In recent times, corruption has reached an endemic proportion that there is urgent and drastic intervention before the entire country collapses (Oluajo, 2017). The print and social media is awashed dailywith stories of endemic corruption in Nigeria both the public and private sector. In Nigeria, corruption was diagnosed to stifle financial growth; lessen financial efficiency and improvement despite the extensive assets available to thecountry. Corruption 
creates poor countrywide picture and loss of revenue. It devalues the quality of life, robs faculties, agricultural sectors, medical institution and welfare services of budget. It discourages overseas investments meant to decrease in overseas Direct funding (Oluajo, 2017).

Various administrative procedures, law enforcement, technological surveillance and judicial mechanism introduced to ensure transparent monitoring and audit, eliminate corruptive discretion of public officials, facilitate information exchange leading to accelerated detection of corruption and punishment of offenders have yielded little result. For example in the Nigerian, several anticorruption agencies and mechanism include: Police " $X$ " Squad by Yakubu Gowon regime (1967-1975); Public Complaints Commission and Code of Conduct Bureau by Murtala Muhammed administration (1975-1976); War Against Indiscipline (WAI) put in place by Buhari/Idiagbon regime (1983-1985); War Against Indiscipline and Corruption (WAIC) in IBB regime (1985-1993) and Sani Abacha’s (1993-1998) established the Code of Conduct Tribunal \& Failed Banks Tribunal. Obasanjo (1999-2007) floated several anti-corruption bodies like the Independent Corrupt Practices and Other Related Offences Commission (ICPC), Economic and Financial Crimes Commission (EFCC), Nigerian Extractive Industries Transparency Initiative (NEITI); Bureau of Public Procurement (BPP); Nigeria Financial Intelligence Unit (NFIU), among others to tackle the problems of corruption in the Nigerian public service. Currently, the President Muhammadu Buhari civilian governmentadded the Presidential Advisory Committee Against Corruption (PACAC) and instituted the Treasury Single Account (TSA) to combat the growing corruption problem. Despite these, perpetrators have continued to find loop holes and different mechanism to beat the system. These interventions have not seeksolutions in looking at human disposition and demographic factors for explanation inwhat prompt individuals involvement in corrupt practices, thus their failures (Oluajo, 2017). Local government is the third tier in Nigeria's federal system identify as the government at the grassroots closest to the people. However, contrary to expectation local governments in Nigeria have been identified as the nurturing ground for corruption due to lack of transparency and accountability in its activities (Abubakar, 2010). Common in the local government is graft, nepotism, wastage, inefficiency and misappropriation of funds (Agbo, 2010). From the ongoing human dispositional factors is central to any intervention in any anti-corruption programme.

Looking at the human factors in anti-corruption fight is the role of dispositional traits and socio-demographic characteristics in the act of corruption. One of the present value 
considered is the problems of dispositional trait relating to corrupt behaviour. Dispositional traits are behaviours that define a person's character and/or personality. Habitual patterns of behaviour, thought, and emotion. It is the overall tendency to respond to situations in stable, predictable ways (Kassin, 2012).Narcissism personality trait is a human trait that defines people who are selfish, egocentric, who tend to covert power, money and influence. Narcissists lack regards for rules that govern interactions with others (Rosenthal \&Pittinsky, 2006). They acquire personal benefits at the expense of others (Glad, 2002), and they careless about societal norms and conforming to societal moral expectations (Kramer, 2003). As such workers who are high narcissism will have tendency to be corrupt. Such individuals circumvent the administrative process to enrich themselves. Examples of such are those who delay presenting document to consenting authority, Bank cheque kiting, misappropriation, nepotism among others.

The second dispositional characteristic is materialism. Materialism is every other construct gaining growing attention from researchers on corruption (Olivia, Tong, \& Wong, 2012). Olivia et al., (2012) depicted "materialism as an introduction defines seeing material belonging and cash as being critical for personal joy and social advancement." Having materialwealth is the basic expectation in a materialistic character's life." Materialism is a prime reason for societal and moral latitudes (Olivia et al., 2012).Belk (1988) related materialism to an inescapable loss of concerns for material wellbeing of others in the society, which make individuals less sensitive to being materially supportive orhavingreadiness to use personal resourcesfor philanthropy, helping friends or family members (Olivia et al., 2012). The more prominent materialistic workers may be slanted to trade off or twist moral rules for personal benefit.

Demographic variables in this study looks at biographical and socioeconomic variables with likelihood of inducing involvement in corruption behaviour. From literature the commonly implicated variables include age, gender, socio-economic status and education. Acceptance of corruption behaviour is believed toreduce with increasing age as youths tend to have more positive attitude to corruption (Torgeler\&Valev, 2006). Male gender has been consistently linked with intention to pay or take bribe (Orces, 2009). Employees’ financial and social position in connection to others, in view of wage, training, and occupation is believed to play a role in corruption behaviour. Corruption is believed to be endemic in developing countries especially countries were the average employees earn below \$1 dollar per day (Swamy et al., 2001; Torgeler \& Valev, 2010). Corruption is seen as a way of 
supplementing for the meager income. Job position, A vocation title can depict the obligations of the position, the level of the activity, or both is linked with level of involvement in corruption behaviour. Being a juniour public servant have been associated with increase tendencies to have positive attitude to bribe taking (Orces, 2009). The last is seen to be central for higher degree of influence in corruption behaviour. Education is accepted to have subjective advantages for diminishing corruption. A portion of the more unmistakable advantage of education is the lessened probability of partaking in wrongdoing and of being captured, expanded propensity to carry on legitimately, and enhanced wellbeing results (Oreopoulos\&Salvanes, 2009). Education may incite persistence and the eagerness to forfeit today for a more noteworthy pick up tomorrow, as understudies discover that work and study pay off through higher evaluations and better openings (Becker and Mulligan, 1997). This could matter for corruption practices, as more taught individuals may esteem the long haul societal great, a less degenerate state, over prompt individual satisfaction which could be increased through reward paying. Likewise, expanded propensities to carry on legitimately and bring down capture rates obviously demonstrate a developing abhorrence for illicit action with more noteworthy education accomplishment. This could influence one's readiness to take an interest in corruption practices. This study thus, looks at the contribution of materialism, narcissism and other socio-demographic variables to corrupt behaviour among civil servants. As a result of the identified gap the study wish to answer the following research hypotheses:

(1) there will be no significant relationship between narcissism, materialism and socio demographic andcorrupt behaviour among employees

(2) Psycho-social factors will have no significant joint and individual prediction of corrupt behaviour among local government workers

\section{Review of Empirical and Related Studies \\ Materialism and corrupt behaviour}

Empirical proof shows that materialism is correlated with corruptive inclinations amongst clients (Muncy \& Eastman, 1998). Empirical results from Indonesia indicated that humans owning excessive materialism and relativism were more attracted to questionable practices, despite the fact that the practices have criminal implication ( $\mathrm{Lu} \& \mathrm{Lu}, 2009$ ). Lu and Lu (2009) examined the link between materialism and work ethics of Indonesians. Outcomes indicated that Indonesians with excessive degrees of materialism and relativism are much more likely to engage in activities which are questionable however legal. Lai Wah, Tong, and Wong 
(2010) tested the connection amongst materialism and the untrustworthy conduct of clients and role of socio-demographic variableson the associationbetweenconsumer moral belief and materialism. A strong association was discovered amongst materialism and customer moral behaviouras age, income and educational attainment all moderatingly affect this association. Ameh (2009) examine the ethical behaviour and beliefs of the construction specialists within the construction procurement chain. He sought to unravel the factors responsible for the corrupt behaviour of the Nigerian construction specialists as well as the character and incidence of the ethical impropriety obtainable at various degrees in the building projects procurement chain. He observed that the award of contracts to professionals was based totally on social ties and private interests was the most rampant among the list of twenty-two most conventional moral impropriety in the industry. Dominant moral ideology of constructing enterprise professionals is situational. Quantity surveyors was perceived as the most vulnerable to bribery; greed and inordinate pursuit of high material gain recognized as reasons for professional ethical impropriety.

\section{Narcissism on corrupt behaviour}

Krejèí, Kvapil, and Semrád (1996) tested the connection between the job delight of the law enforcement officials and their attitudes towards the professional ethic scale. They determined that cops low on job satisfaction became observed to be excessive in narcissism and unethical behaviour. Afolabi and Adesina (2006) tested the connection among task frustration, narcissism, demographic variables and expert moral behaviour amongst Nigerian police officers. Their findings demonstrated a sizeable negative association between narcissism and professional ethical behaviour. Rijsenbilt and Commandeur (2012) tested the relationship between feasible signs of CEO's narcissism and fraud. Their findings verify the effect of CEO's narcissism on potential fraudulent as theyfound a high-quality courting mental attitude of CEO's narcissism as a capacity for fraud. Narcissism has been diagnosed as a leading factor to fraud behaviour (Price\& Norris, 2009). Blickle et al. (2006) confirmed that convicted fraudsters and corruption offenders had substantially higher levels of narcissism than a group of noncriminal white-collar executives. Misappropriation of company assets with the aid of administrative control was associated with narcissistic behaviour, for example intense ambition to the point of acting pushed (Duffield \&Grabosky, 2001).

\section{Socio-demographic variables and corruption behaviour}


For this situation, education is contrarily identified with the probability of bribing public officers. Orces, (2008), found that riches, education, living in a greater city and being male all improve the probability of giving pay off to the police while age diminishes the probability of giving bribe. Orces, (2009a). Additionally showed thatwealth, education, living in a urban city and being male was related with giving pay off among civil servants same for general medicinal workers, where she discovered comparative outcomes for all factors aside from education (Orces, 2009b). Utilizing these studies scientists have demonstrated that females are fundamentally less tolerant of corruption practices than guys and that females (Kaffenberger, 2012). Age likewise brings down a person's resistance for involvement in corruption practices (Kaffenberger, 2012). Attile, (2008) found that women were less involved in corruption practicesthan men, those living in rural territories see less corruption than those in urban zones, those in government organization see higher corrupt behaviour, and education has blended impacts depending upon the sort of corruption practices considered (Attile, 2008). At the point when education is talked about with regards to corruption behaviour, it is most generally inspected at the nation level. Cross-country research have settled that more elevated amounts of total education in a nation are related with bring down levels of corruption practices as estimated by total rankings (Lederman et al., 2005).

\section{METHOD}

Research Design: This study was conducted using a cross-sectional research method

\section{Participants:}

Themulti-stage sampling technique Purposive sampling technique was used as the samplea total of three hundred and fifty (350) civil servants in the employment of Odeda LGA. The participants' age ranges between 25 to 56 years old with a mean age of 43.44 years( $S . D=10.20$ years). 52.3\% (183) participants were females. The participants were from finance (20.9\%) administration (19.4\%) community development (27.1\%), planning (29.1\%) and health (3.4\%). Job position revealed that 53.1\%were juniour employees; $40.9 \%$ were seniour employees; and $6.0 \%$ were from leadership team. Highest educational attainment shows that $8.6 \%$ were WAEC certificate holder; Diploma (28.6\%); HND/B.Sc (46.3\%); and Postgraduate degree (16.6\%). In terms of their marital status, 154 (44.0\%) were singles and 45.7\% (160) were married and 3.4\% (12) separated; and 6.9\% (24) were divorced. Participants length of service in their present employment are as follows: 1-5 years were 154 (44.0\%); 6-10 years were 101 (28.9\%); 11-15 year were 27 (27.7\%); 16-20 years 
were 54 (15.4\%); and finally, 21 and above years were 14 (4.0\%). In the study, participants level 71.4\% were of Level 1-6 and 28.6\% were of level $7-12$.

\section{Research instrument}

A self-report questionnaire structured questionnaire was used in data collection for the study. The questionnaires have proven psychometrically sound properties over the years. Section A measured participants' socio-demographic variables this include age, gender, education, job position, years of experience and level. Narcissism behaviour was captured using the Hyperactive Narcissism Scale (HNS), a 10-item self-reported scale developed by Hendin and Cheek (1997). Participants responded to scale on five-point Likert scale response format scored from 1 (strongly disagree) to 5 (strongly agree). Scale scores are computed by summing the responses to each scale's items, and the total score. Higher scores indicate higher narcissism. The scale have a good reliability $(\alpha=0.78)$. 0.68 alpha was obtained in the present study.Materialism was measured using the 24item materialism scale developed by Belk (1985). Participants are required to indicate a degree of agreement with each statement using a five-point Likert scale ranging from 1 (strongly disagree) to 5 (strongly agree). The author's reporteda reliability of 0.84 alpha. For the current study, 0.68 and Split Half reliability of .74 was reported. Corrupt work behaviour was captured using the unethical Work Behaviour Scale developed by Akaah and Lund (1994). The 16-item self-reported scale was rated on a 5-point Likert scale ranging from 1 (strongly disagree) to 5 (strongly agree).Overall score ranges from 16 to 80. Higher scores indicate high Corrupt Work Behaviour. Akaah and Lund (1994) reported meritorious reliability for the scale $(\alpha=.81)$. For the current study, 0.77 Cronbach's alpha and Split Half reliability statistics of .76 was obtained.

\section{Procedure of the Study}

The researchers sought permission from the Ogun State Civil Service Commission to conduct the study. The researcher use the multistage sampling technique to distribute the questionnaires at the different offices identified based on the number of departments in the Odeda secretariat, Odeda. The respondents selected were first informed about the intentions of researcher and those willing to participate in the study were given questionnaire to fill while explanation was made where necessary. An agreed period of between two to three days interval was given to the participants for the completion and return of the questionnaire which was at their own convenient time.

\section{Data Analysis}

The data was analyzed using SPSS 20.0 statistical software. Descriptive statistics and inferential statistical instruments wereused for analysis. For the test of instrument reliability, the Cronbach 
alpha was used to analyze the questionnaire items. Objective of the study was assessed via Pearson Product Moment Correlation analysis (PPMC), and Multiple Regression analysis at $p \leq .05$ level of significance.

\section{RESULTS}

\section{Hypothesis I}

The first hypothesis tested states that there will be no significant relationship between narcissism, materialism and socio demographic andcorrupt behaviour among employees using Zero Order correlation analysis. The result is presented in Table 1.

Table 1: Summary table of zero order matrix showing the correlation coefficients narcissism, materialism, and socio demographic variables on corrupt behaviour.

\begin{tabular}{|c|c|c|c|c|c|c|c|c|}
\hline Variables & Mean & S.D & 2 & 3 & 4 & 5 & 6 & 7 \\
\hline 1. Corrupt behaviour & 25.69 & 5.44 & $-.534^{* *}$ & $.566^{* *}$ & $-.142^{* *}$ & $.181^{* *}$ & -.090 & $-.126^{*}$ \\
\hline 2. Narcissism & 16.33 & 3.82 & -- & $.667^{* *}$ & $-.281^{* *}$ & $.352^{* *}$ & $-.257^{* *}$ & $-.229^{* *}$ \\
\hline 3. Materialism & 27.09 & 6.00 & & --- & $-.225^{* *}$ & $.250^{* *}$ & $-.168^{* *}$ & -.095 \\
\hline 4. Age & 2.34 & 1.00 & & & --- & -.078 & $.144^{* *}$ & .043 \\
\hline 5. Academic qualification & 2.71 & .84 & & & & --- & $.155^{* *}$ & .099 \\
\hline 6. Marital status & 1.73 & .82 & & & & & --- & $.325^{* *}$ \\
\hline 7. Length of service & 1.22 & 2.07 & & & & & & --- \\
\hline
\end{tabular}

From Table 1, it was observed that Narcissism ( $\mathrm{r}=.53 ; p<.01)$; materialism $(\mathrm{r}=.57 ; p<.01)$; and highest academic qualification $(r=.18$; $\mathrm{p}<.01)$ were significant positive predictors of corruptive behaviour. Being high on narcissism, materialism and having high academic qualification was associated with increasing corruption tendencies. However, in contrast decreasing age $(r=-.14$; $\mathrm{p}<.01)$; shorter length of service in the present employment $(\mathrm{r}=-.13 ; \mathrm{p}<.05)$; were associated with corrupt behaviour. Hence, the objective that narcissism, materialism and socio demographic variables would correlates ofcorrupt behaviour among employees of Odeda Local Government Area in Ogun State was supported in this study. The important psycho-social predictors of corrupt behaviour were also tested using multiple regression analysis. The result is presented in Table 2 .

Table 2: Summary of multiple regression analysis showing the influence of Materialism, Narcissism, gender, age, marital status, length of service and educational qualification on corrupt behaviour

\begin{tabular}{lccccccc}
\hline Variable & $\beta$ & t-value & Sig & R & $\mathrm{R}^{2}$ & $\mathrm{~F}$ & $\mathrm{P}$ \\
\hline Materialism & .34 & 5.06 & $<.01$ & & & & \\
Narcissism & .31 & 4.54 & $<.01$ & 0.59 & 0.36 & 81.07 & $<.01$ \\
Age & .07 & 1.54 & $>.05$ & & & & \\
Sex & -.08 & -1.59 & $>.05$ & & & &
\end{tabular}


Length of service $\quad-.10 \quad-2.21 \quad<.05$

$\begin{array}{llll}\text { marital status } & .03 & .67 & >.05\end{array}$

$\begin{array}{llll}\text { Educational qualification } & .27 & 5.27 & <.01\end{array}$

From the Table 2, the result revealed that materialism, narcissism, age, sex, and educational, marital status jointly contributed $\left(\mathrm{R}^{2}=.36\right) 36 \%$ of the significant change observed on reported corruptive behaviour $[\mathrm{F}(7,343)=81.07 ; \mathrm{p}<.001]$. Meaning that the prescience materialism, narcissism, age, sex, and educational background, marital status and job positionincreases the prediction of local government employees' corruption practices by $36 \%$. Materialism $(\beta=.34 ; \mathrm{t}=$ 5.05; $\mathrm{p}<.01)$, and narcissism $(\beta=.31 ; \mathrm{t}=4.54 ; p<.01)$ were significant positive independent predictors of corruptive behaviour among employees of the participants. Employees who materialistic and self-centered were more corruptcompared to employees with low materialism and narcissistic drive. Further length of service $(\beta=-.10 ; \mathrm{t}=-2.21 ; p<.01)$, and educational qualification $(\beta=.27 ; \mathrm{t}=5.27 ; \mathrm{p}<.01)$ were also significant independent predictors of corruption practices. Local government employees who have higher qualification and with shorter years in service were corrupt in their work activities compared to those lower qualification with longer years of experience. However, the influence of age, sex, and marital status were not significant independent predictors of local government employees’ corruption practices.

\section{Discussion}

The study was able to establish the psycho-social factors affecting corruption among civil servants in Ogun state. The result of the study showed that materialism and narcissism correlated with corruption practices among employees in local government. Materialism and narcissism were significant independent predictors of employees in local government corruption practices as corruption practices behaviour increases with high materialism and narcissism. Employees who materialistic and self-centered were more corrupt. This supports the findings of Rudmin and Richins (1992) who demonstrated that people high on materialism have questionable behaviour and the work of Barrett (1992) which associated certain types of unethical behaviour with greater amounts of materialism. In the identical vein, the findings support Warren et al., (2002) demonstrated good sized relationship between persona problems and crime. Moreover, an effective correlation between Narcissistic personality disorder and incarceration for violent crimes (Warren et al., 2002). Length of service and educational status were correlates and predictors of engagement in corrupt practices. This finding is in contrast with the study of Adebayo (2005) who found that gender influence the ethical behaviour of the Nigerian police officers. The findings however agree with the work of Ahmadi and Ashrafjahani (2011) also found that education was significant predictor of unethical 
behaviours among managers in Iran. In the same vein, the findings support Wolfe and Hermanson (2004) who found that job position was associated fraudulent behavior among chief executive officers. The finding gives credence to the study of Lai Wah, Tong, and Wong (2010) who that demographic variable of education has a moderating impact on the relationship with unethical behaviour.

\section{Implication and Conclusion}

This study has established that psychosocial factors predicted local government employees' corrupt behaviour. Materialism and narcissism were significant independent predictors of corruption practices. It was also confirmed that educational qualification and religious affiliation predicted corruption practices. This shows that personality and socio-cultural milieu is a major factor in the increasing level of corruption in Nigeria. Thus, societal and reorientation remain an imperative towards removing corruption as a serious impediment to sustainable development, especially in developing countries like Nigeria. Our research implication for research trend on corruption behaviour. In this respect, this inquiry is another attempt at linking pathological traits to corruption behaviour. The level of endemic corruption in the Nigerian public space calls for rigorous research in establishing factors promoting this unethical behaviour. To a great extent this study answers the questionsabout the role personality traits in employee's engagement in corruption behaviour. Reported exhibition of high levels of grandiosity, sense of entitlement and self-centeredness among local government employeewas associated with self-reported subversion of the public service rules and conversion of government resources to personal use. In addition, employeeshigh on materialismalso expressed the same decision to subvert the system in catering for their attraction for materialistic life styles. People of high materialistic and narcissistic tendenciesoften do not draw the line between public and personal property, they live for the present and think less of the implication of their behaviour for the future. From the pragmatic approach, this inquiry is an anti-corruption strategy design to bring to awareness dispositional factors influencingcorruption behaviour among Nigerian employees. Irrespective of the limitation in modifying dispositional characteristics, creating awareness of predisposing factorsassociated with unrealistic beliefs and work philosophyleading toinvolvement in corruption behaviours empowers individuals with psychological skills to deal with them. In the same vein, government awareness about personality traits fueling irrational beliefs associated with corrupt behaviour can help anti-corruption agencies and institutions become more effective in inhabiting people's irrational beliefs in corruption. The government can decrease their corrupt behaviours by discouraging their irrational belief leading to 
corruption through inculcation of merit-based work ethic systemeradicates bribe taking and nepotism. In addition, consistent exposure of civil servants toinformation about anti-corruption policies, the punishment it attracts can help them to be acutely aware of the consequences of being involve in corruption practices. From the human resource perspective being vigilant and offering personality assessment during recruitment process can help screen out applicants with shady character and personality disorders. Serious background checks can also help reduce the incident of hiring corrupt persons. Psychologists have to offer formal counselling session to employees with unethical behaviours. These will assist them sense valued and enable them overcomes problems of irrational thought or beliefs in demanding situations during ethical decision making. This study has potential limitations as well. One of the limitations of this study is the use of only local government personnel in Odeda LGA, Ogun state, thus external validity is a concern. Second limitation arisesfrom the cross-sectional data, as no causal relationships can be established without longitudinal studies. Third, there is high likelihood of socially desirable responding. Studies on unethical behaviourcan be confounded by socially desirable responding.

\section{REFERENCES}

Abubakar, A.Y. (2010), The Role of Local Government in Social, Political and Economic Development inNigeria. Zaria, Department of Local Government Studies, Institute of Administration, Ahmadu BelloUniversity, Zaria.

Afolabi, A.O. \& Adesina, A.A. (2006) Influence of job frustration, narcissism and demographic variables onattitudes towards professional ethical behavior among Nigerian Police officers. African.Journal of Psychos-social Issues, 9(1): 37-45.

Agbo, A.J. (2010), Meddling in LG Allocation,www.nigeria-local-government.com. Retrieved 20/09/2012.

Ahmadi ,A.A \&Ashrafjahani, A. (2011), Factors affecting ethical perceptions and attitudes of managers, African Journal of Business Management. 5(26) 10452-10461.

Akaah, I.P., \&Lund,D.(1994). "The Influence of Personal and Organizational Values on Marketing Professionals’ Ethical Behaviour.”Journal of Business Ethics 13: 417-430.

Attile, G. (2008). "How Do African Populations Perceive Corruption:

MicroeconomicEvidence from Afrobarometer Data in Twelve Countries.” Centre

D’Etudes et de Recherches Sur le Developpement International Working Paper 200811. 
Barrett, A. (1992). Crime Waves Spread very Democratically In Czechoslovakia; Even Toilet Paper Is Locked Away As New Breed of Thief Hails Western Materialism, The Wall Street Journal, B7B.

Belk RW. (1985). Materialism: Trait Aspects of Living in the Material World. Journal of Consumer Research 12(3):265-280.

Belk RW. (1988). Third World Consumer Culture. In Kumku E., Firat A. F. (eds) Marketing and Development:Towards Broader Dimensions.103-127. Greenwich, CT: JAI Press.

Blickle, G., Schlegel, A., Fassbender, P., \& Klein, U. (2006). Some personality correlates of business white-collar crime. Applied Psychology: An International Review, 55, 220 233.

Diagnostic and Statistical Manual of Mental Disorders ( $4^{\text {th }}$ ed). (1994) Washington, DC: American Psychiatric Association.

Duffield, G. \&Grabosky, P. (2001). The psychology of fraud. Trends and issues in crime and criminal justice 200. Australian Institute of Criminology, Canberra.

Enweremadu DU (2010). Anti-corruption policies in Nigeria under Obasanjo and Yar'Adua: what to do after 2011? Discussion Paper, No 1, November,2010 Friedrich Ebert Stifung. Marrakesh Street, Wuse, Abuja.

Gire, J. T. (1999). “A Psychological Analysis of Corruption in Nigeria”. Corruption. Online. 19 March, 2004.

Glad, B. (2002), "Why tyrants go too far: malignant narcissism and absolute power”, Political Psychology, 23 (1) 1-37.

Hendin, H. M., \& Cheek, J. M. (1997). Assessing Hypersensitive Narcissism: A Reexamination of Murray's Narcissism Scale. Journal of Research in Personality, 31, 588-599.

Kaffenberger, M., (2012). “The effect of educational attainment on corruption participation in sub-Saharan Africa”, Graduate School of Vanderbilt University.

Kassin, S. (2012). Why confessions trump innocence. American Psychologist, 67, 431-44.

Krejèí, P., Kvapil, J. \&Semrád, J. (1996). The relation between job satisfaction, job frustration and narcissism and attitudes towards professional ethical behavior among police officers. College of Police and Security Studies - Slovenia. Policing in Central and Eastern Europe: comparing firsthand knowledge with experience from the West [Online]. Disponívelem: <http://www.unojust.org>

Kwong, K. K., Yau, H. M., Lee, S. Y., Sin, Y. M., \&Tse, C. B. (2003). The Effects of Attitudinal and Demographic Factors on Intention to Buy Pirated CDs: The Case of Chinese Consumers. Journal of Business Ethics, 47(3), 223-235. http://dx.doi.org/10.1023/A:1026269003472

Lu, L. C., \& Lu, C. J. (2009). Moral Philosophy, Materialism, and Consumer Ethics: An Exploratory Study in Indonesia, Journal of Business Ethics, 94(2), 193210.http://dx.doi.org/10.1007/s10551-009-0256-0 
Lui, O.L.A., Tong, C., \&Wong, A. (2012). TheImpact of Materialism on Consumer. Ethics: An Empirical Study on Adult Students in Hong Kong. Journal of Management Research, 4(2), 51-. 87.

Muncy, J.A, \& Eastman JK. (1998). Materialism and Consumer Ethics: An Exploratory Study. Journal of BusinessEthics17(2): 137-145.

Olivia, L. W. L., Tong, C., \& Wong, A. (2012). The impact of materialism on consumer ethics: An empirical study on adult students in Hong Kong. Journal of Management Research, 4(2), 51-87. http://dx.doi.org/10.5296/jmr.v4 i2.1233.

Oluajo, B. (2017) Clapping With One Hand: Nigeria’s Failing Anti-Corruption Strategies, retrieved from https://opinion.premiumtimesng.com/2017/04/20/clapping-one-handnigerias-anti-corruption-strategies-babatunde-oluajo/

Orces, D. (2008). “Corruption Victimization by the Police.” AmericasBarometer Insights 3.

Orces, D. (2009a). “Corruption Victimization by Public Employees.” AmericasBarometer Insights 13.

Orces, D. (2009b). "Corruption Victimization in the Public Health Sector.” AmericasBarometer Insight 30.

Oreopoulos, P., \&Salvanes, K.G.(2009). "How Large are Returns to Schooling? Hint: Money Isn’t Everything.” NBER Working Paper 15339.

Price, M., \& Norris, D. M. (2009). White collar crime: Corporate and securities and commodities fraud. The Journal of the American Academy of Psychiatry and the Law, 37(4), 538-544.

Reitman, V. (1996). Japan's new growth industry: schoolgirl prostitution - prevention efforts are blocked by tax laws - and mother's groups. Wall Street Journal (Eastern Edition). 2(October), A14.

Richins, M. L., \& Dawson, S. (1992). A Consumer Values Orientation for Materialism and its Measurement: Scale Development and Validation, Journal of Consumer Research, 19(3), 303-316. http://dx.doi.org/10.1086/209304

Rijsenbilt, A., \& Commandeur, H. (2012). Narcissus Enters the Courtroom: CEO Narcissism and Fraud. Journal of Business Ethics, 117 (2), 413-429; DOI: 10.1007/s10551-0121528-7.

Rosenthal, S.A. \& Pittinsky, T.L. (2006), “Narcissistic leadership”, Leadership Quarterly, Vol. 17 ( 6) 617-633.

Rudmin, F., \& Richins, M. (1992). Meaning, Measure and Morality of Materialism, Association for Consumer Research, Provo, UT.

Swamy, Anand, Stephen Knack, Young Lee and Omar Azfar. 2001. “Gender and Corruption.” Journal of Development Economics 64: 25-55.

Sykes, T. (1994), The Bold Riders: Behind Australia's Corporate Collapses, Allen and Unwin, Sydney.

Torgler, B.\&Valev. N.T.(2010). “Gender and Public Attitudes Toward Corruption and Tax Evasion.” Contemporary Economic Policy 28 (4): 554-68. 49. 
Treviño, L. K., Weaver, G. R., Gibson, D. G., \& Toffler, B. L. (1999). Managing ethics and legal compliance: What works and what hurts. California Management Review,41(2), 131-151.

Turnley, W. H., \& Feldman, D. C. (2000). Re-examining the effects of psychological contract violations: unmet expectations and job dissatisfaction as mediators. Journal of Organizational Behaviour, 21, 25-42.

Ward, Scott \& Daniel Wackman (1971), "Family and Media Influences on Adolescent Consumer Learning," American Behavioral Scientist, 14, 415-427.

Warren,J.I., Burnette, M., South, S. C., Chauhan, P., Bale, R., \&Friend, R. (2002). Personality disorders and violence among female prison inmates.Journal of the American Academy of Psychiatryand the Law Online, 30, 502-509.

Wolfe, D., \& Hermanson, D. R. (2004). The fraud diamond: Considering four elements of fraud. The CPA Journal,74 (12), 38-42.

Torgler, B.\&Valev. N.T.(2006). “Corruption and Age.” Journal of Bioeconomics8: 133-45.

Truex, Rory. 2011. “Corruption, Attitudes, and Education: Survey Evidence from Nepal.” World Development 39 (7): 1133-42. 